\title{
COMPARISON OF TWO DIFFERENT METHODS FOR TIGECYCLINE SUSCEPTIBILITY TESTING IN ACINETOBACTER BAUMANNII
}

\author{
Branka Bedenić, ${ }^{1,2}$, Gordana Cavrić ${ }^{3}$, Mirna Vranić-Ladavac ${ }^{4}$, Nada Barišić ${ }^{5}$, \\ Natalie Karčić ${ }^{4}$, Tatjana Tot ${ }^{5}$, Aleksandra Presečki-Stanko ${ }^{2}$, Amarela Lukić-Grlić ${ }^{1,6}$, \\ Sonja Frančula-Zaninovićc ${ }^{7}$ and Katherina Bernadette Sreter ${ }^{8}$
}

${ }^{1}$ Department of Microbiology, School of Medicine, University of Zagreb, Zagreb, Croatia; ${ }^{2}$ Department of Clinical and Molecular Microbiology, Zagreb University Hospital Centre, Zagreb, Croatia;

${ }^{3}$ Department of Intensive Care, Merkur University Hospital, Zagreb, Croatia;

${ }^{4}$ Department of Microbiology, Public Health Institute of Istria County, Pula, Croatia;

${ }^{5}$ Department of Microbiology, Karlovac General Hospital, Karlovac, Croatia;

${ }^{6}$ Department of Clinical Microbiology, Zagreb Children's Hospital, Zagreb, Croatia;

${ }^{7}$ Zagreb Health Centre, Zagreb, Croatia; ${ }^{8}$ Department of Clinical Immunology,

Pulmonology and Rheumatology, Sestre milosrdnice University Hospital Centre, Zagreb, Croatia

SUMMARY - Tigecycline susceptibility testing (TST) presents a tremendous challenge for clinical microbiologists. Previous studies have shown that the Epsilometer test (E-test) and Vitek 2 automated system significantly overestimate the minimum inhibitory concentrations for tigecycline resistance compared to the broth microdilution method (BMM). This leads to very major errors or false susceptibility (i.e. the isolate is called susceptible when it is actually resistant). The aim of this study was to compare E-test against BMM for TST in carbapenem-resistant and carbapenem-susceptible Acinetobacter (A.) baumannii and to analyze changes in tigecycline susceptibility between two time periods (2009-2012 and 2013-2014), with BMM as the gold standard. Using the EUCAST criteria, the rate of resistance to tigecycline for the OXA-23 MBL-positive, OXA-23 MBL-negative and carbapenemase-negative strains for BMM was 54.5\% (6/11), 29.4\% (5/17) and 2.7\% (1/37), respectively; the OXA-24/40 and OXA-58 producing organisms did not exhibit any resistance. With E-test, all OXA-23 MBL-positive organisms (11/11), 23.5\% (4/17) of OXA-23 MBL-negative, and 4.1\% of OXA-24/40 (3/74) strains displayed tigecycline resistance; there were no resistant strains among the OXA-58 and carbapenemase-negative isolates. Resistance emerged in the bacterial isolates from 2013 to 2014. Although tigecycline does not display cross-resistance, the highest rates of resistant $A$. baumannii isolates were observed among those producing VIM MBL, regardless of the testing method. These findings suggest that the commercial E-test does not provide reliable results for TST of $A$. baumannii. Further confirmation with the dilution method should be recommended, particularly in cases of serious infections.

Key words: Tigecycline; Disk diffusion, antimicrobial tests; Microbial sensitivity tests; Acinetobacter baumannii; Drug resistance, microbial

\section{Introduction}

Acquired carbapenem resistance is an emerging problem in Acinetobacter (A.) baumannii due to the production of acquired carbapenemases of class $\mathrm{A}$
Correspondence to: Prof. Branka Bedenic, $M D, P h D$, Department of Clinical and Molecular Microbiology, Zagreb University Hospital Centre, Kišpatićeva 12, HR-10000 Zagreb, Croatia E-mail: branka.bedenic@kbc-zagreb.hr, bbedenic@mef.hr Received July 9, 2018, accepted November 13, 2018 
$(\mathrm{KPC})^{1}$, class B metallo- $\beta$-lactamases (MBLs) of the IMP, VIM, SIM and NDM families ${ }^{2-6}$, and class D carbapenem-hydrolyzing oxacillinases (OXA-23-, OXA-40-, OXA-58-, OXA-143- and OXA-238-like) $[\mathrm{CHDL}]^{7-12}$. Carbapenem-resistant $A$. baumannii (CRAB) isolates have been reported worldwide ${ }^{13}$. Carbapenem resistance in $A$. baumannii is a growing concern in Croatia and neighboring countries ${ }^{14-20}$. In addition to the hospital setting, CRAB has also been identified in environmental samples in Croatia ${ }^{21-23}$. $\mathrm{CRAB}$ isolates are frequently associated with serious infections such as ventilator-associated pneumonia, septicemia and urinary tract infections, specifically in intensive care units ${ }^{24-25}$. They are often a cause of wound, skin and soft tissue infections, and secondary meningitis ${ }^{25}$.

Tigecycline and colistin are often last-resort antibiotics for the treatment of infections associated with carbapenemase-producing organisms. Tigecycline, the first semisynthetic glycocycline, is a minocycline derivative that overcomes major tetracycline resistance mechanisms ${ }^{26}$. However, tigecycline resistance has also emerged $^{27}$. Therapeutic decisions often rely on appropriate susceptibility testing. The issue is that tigecycline susceptibility testing (TST) remains a major challenge for clinical microbiologists. Thus far, there are no clear guidelines established by either the Clinical and Laboratory Standards Institute (CLSI) ${ }^{28}$ or the European Committee on Antimicrobial Susceptibility Testing (EUCAST) for TST of $A$. baumannii.

In most studies, the breakpoints applied for Enterobacteriaecae include the susceptibility breakpoint of $\leq 1 \mathrm{mg} / \mathrm{L}$ and the resistance breakpoint of $\geq 4 \mathrm{mg} / \mathrm{L}$. Disk-diffusion test is not appropriate for susceptibility testing for tigecycline. Previous studies have shown that the Epsilometer test (E-test) and Vitek 2 system significantly overestimate the minimum inhibitory concentrations (MICs) of tigecycline compared to the broth microdilution method (BMM), leading to very major errors (i.e. false susceptibility) ${ }^{29,30}$. The aim of this study was to compare two different methods for TST (E-test and BMM) in carbapenem-resistant and carbapenem-susceptible $A$. baumannii and to analyze dynamic changes in tigecycline susceptibility between two collection periods (2009-2012 and 2013-2014). The first period (2009-2012) was chosen because it was in that time-frame that the first carbapenem-resistant isolates were identified in both countries (Re- public of Croatia and Republic of Bosnia and Herzegovina). During the second period (2013-2014), it was observed that tigecycline resistance had emerged and this prompted further evaluation of its prevalence and TST problems. In this study, BMM was considered as the gold standard for TST.

\section{Material and Methods}

\section{Bacteria}

During the two collection periods, a total of 154 bacterial isolates were obtained. Within the scope of this multicentre study, the isolates from 2009 to 2012 were retrieved from 13 different hospital centers in Croatia and from the Mostar General Hospital in Bosnia and Herzegovina. The isolates from the second period (2013-2014) were collected in two centers in Croatia, the Pula General Hospital and Godan Nursing Home in Zagreb. Bacterial strains were identified by conventional biochemical testing (matrix-assisted laser desorption/ionization time-of-flight mass spectrometry, MALDI-TOF MS) and verified by polymerase chain reaction (PCR) for bla ${ }_{\text {OXA-51 }}$ gene. $\mathrm{Mo}^{-}$ lecular characterization of carbapenem resistance was performed as in previous studies ${ }^{16-20}$.

\section{Antibiotic susceptibility testing}

The isolates were classified as multidrug-resistant (MDR), extensively drug-resistant (XDR) or pandrug-resistant (PDR) according to Magiorakos et al. ${ }^{31}$. Susceptibility to tigecycline was determined by BMM and E-test. Antimicrobial susceptibility was confirmed by BMM in Mueller-Hinton broth in 96-well microtiter plates according to the CLSI guidelines ${ }^{28}$. Pseudomonas aeruginosa ATCC 27853 and A. baumannii ATCC 19606 were used as quality control strains. Since CLSI does not have interpretative criteria for TST for A. baumannii, resistance rates were calculated according to the EUCAST criteria for Enterobacteriaceae $^{32}$ or the U. S. Food and Drug Administration (FDA) criteria ${ }^{33}$, with resistance breakpoints of $>2$ or $\geq 8 \mathrm{mg} / \mathrm{L}$, respectively.

\section{Interpretation of data}

Categorical agreement (CA) was defined as the percentage of isolates recorded in the same susceptibility category by BMM and E-test as defined previously 


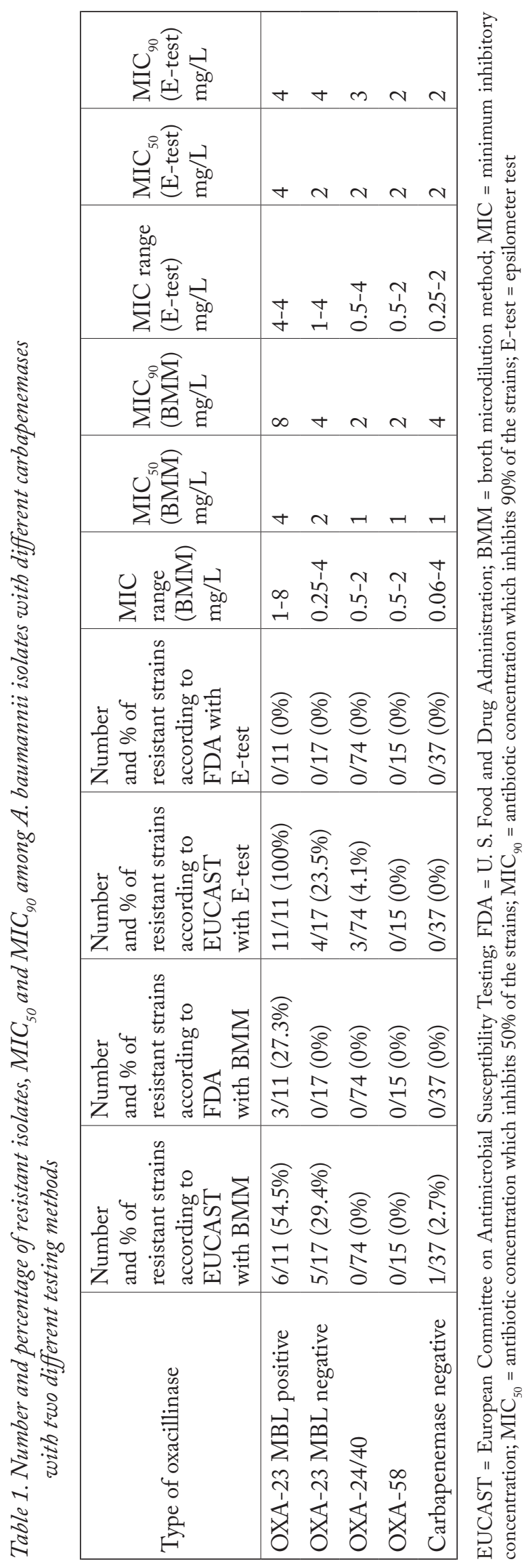

by Zarkotou et al. ${ }^{30}$. Category discrepancies were grouped as follows: (i) very major errors (VME) in cases where BMM indicated resistance and the comparative method indicated susceptibility; (ii) major errors (ME) when an isolate was categorized as susceptible by BMM and resistant by the comparative method; and (iii) minor errors $(\mathrm{mE})$ when there was one interpretation category difference between BMM and the comparative method. Essential agreement (EA) was considered to be the percentage of MICs within 1 doubling dilution of the MIC determined by $\mathrm{BMM}^{30}$.

\section{Results}

Isolates with acquired oxacillinases were labeled MDR or XDR, as described by Magiorakos et al. ${ }^{31}$. When a MIC breakpoint of $>2 \mathrm{mg} / \mathrm{L}$ was applied according to the EUCAST criteria for defining resistance to tigecycline ${ }^{32}$, the rate of resistance for BMM was 54.5\% (6/11) for OXA-23 MBL-positive, 29.4\% (5/17) for OXA-23 MBL-negative, and 2.7\% (1/37) for carbapenemase-negative strains. The OXA-24/40and OXA-58-producing organisms did not exhibit any resistance. In contrast, in E-test, all OXA-23 MBL-positive organisms (11/11), 23.5\% (4/17) of OXA-23 MBL-negative, and 4.1\% (3/74) of OXA$24 / 40$ strains showed resistance to tigecycline, as displayed in Table 1. There were no resistant strains among the OXA-58 and carbapenemase-negative isolates. Using the FDA criteria with a resistance breakpoint of $\geq 8 \mathrm{mg} / \mathrm{L}^{33}$, no resistant isolates were detected, regardless of the testing method. The strains collected from 2009 to 2012 exhibited full susceptibility to tigecycline. However, resistance emerged in those obtained during the 2013-2014 period.

The $\mathrm{MIC}_{90}$ ranged from $2 \mathrm{mg} / \mathrm{L}$ (OXA-24/40 and OXA-58) to $8 \mathrm{mg} / \mathrm{L}$ (OXA-23 MBL positive) with BMM and from $2 \mathrm{mg} / \mathrm{L}$ (OXA-24/40, OXA-23 MBL-negative and OXA-58) to $4 \mathrm{mg} / \mathrm{L}$ (OXA-23 MBL positive) in E-test. The $\mathrm{MIC}_{50}$ varied between 1 and $4 \mathrm{mg} / \mathrm{L}$ with $\mathrm{BMM}$ and between 2 and $4 \mathrm{mg} / \mathrm{L}$ in E-test (Table 1).

When BMM was considered the gold standard for antibiotic susceptibility testing, 5 (45.5\%) MBL-positive and 8 (10.7\%) OXA-24/40 isolates were noted as resistant instead of susceptible, demonstrating a $\mathrm{ME}$ of E-test (Table 2). VME (i.e. resistant strain being classified as susceptible) was identified in only one 
Table 2. Rate of errors in E-test compared to broth microdilution method

\begin{tabular}{|l|l|l|l|l|l|}
\hline Type of oxacillinase & $\%$ of VME & $\%$ of ME & $\%$ of $\mathrm{mE}$ & $\%$ of EA & $\%$ of CA \\
\hline OXA-23 MBL- positive & $0 / 11(0 \%)$ & $5 / 11(45.5 \%)$ & $5 / 11(45.5 \%)$ & $9 / 11(81.8 \%)$ & $6 / 11(54.5 \%)$ \\
OXA-23 MBL- negative & $0 / 17(0 \%)$ & $0 / 17(0 \%)$ & $5 / 17(29.4 \%)$ & $15 / 17(88.2 \%)$ & $12 / 17(70.6 \%)$ \\
OXA-24/40 & $0 / 75(0 \%)$ & $8 / 75(10.7 \%)$ & $44 / 75(58.7 \%)$ & $71 / 75(94.7 \%)$ & $44 / 75(58.7 \%)$ \\
OXA-58 & $0 / 15(0 \%)$ & $0 / 15(0 \%)$ & $5 / 15(33.3 \%)$ & $14 / 15(93.3 \%)$ & $10 / 15(66.7 \%)$ \\
Carbapenemase negative & $1 / 37(2.7 \%)$ & $0 / 37(0 \%)$ & $10 / 37(27.0 \%)$ & $32 / 37(86.5 \%)$ & $10 / 37(27.0 \%)$ \\
\hline
\end{tabular}

$\mathrm{VME}$ = very major error; $\mathrm{ME}=$ major error $\mathrm{mE}=$ minor error; $\mathrm{EA}=$ essential agreement $\mathrm{CA}$ = categorical agreement

(2.7\%) of the carbapenemase-negative strains (Table 2). The rates of $\mathrm{mEs}$ were $58.7 \%, 45.5 \%, 33.3 \%, 29.4 \%$ and $27.0 \%$ for OXA-24/40, MBL, OXA-58, OXA-23 MBL-negative and carbapenemase-negative isolates, respectively. The highest rate of EA was observed for OXA-24/40 (94.7\%), followed by OXA-58 (93.3\%), OXA-23 MBL-negative (88.2\%), carbapenemasenegative (86.5\%), and OXA-23 MBL-positive (81.8\%) strains (Table 2). The CA was highest in OXA-23 MBL-negative strains (70.6\%) and lowest in carbapenemase-negative strains (27.0\%).

\section{Discussion}

Although tigecycline does not display cross-resistance, the highest rates of resistance were observed among the VIM MBL-producing isolates, regardless of the testing method. Emergence of tigecycline resistance was detected for isolates from the 2013-2014 collection period, whereas those from 2009 to 2012 were fully susceptible. Tigecycline testing by E-test produced higher MICs, yielding $\mathrm{ME}$ in $45.5 \%$ of MBL-positive isolates, while VME was detected in only one carbapenemase-negative strain. The rates of EA of approximately $80 \%$ to $90 \%$ and CA of $60 \%$ to $70 \%$ were similar to those found by Zarkotou et al. ${ }^{30}$. There are no published studies so far on the accuracy of particular tests in isolates with different carbapenemresistance mechanisms.

According to the results of this study, E-test did not provide reliable results. Hence, these should be substantiated by the dilution method. This is especially important in case of severe infections. Although considered the gold standard, BMM is laborious, timeconsuming and requires educated staff. In addition, these findings confirm the elevated MICs of tigecycline by E-test compared to BMM, as previously de- tailed by other authors. However, the discrepancies between these two methods were less pronounced in our study than in the published literature, where the MICs of BMM were overestimated two- to three-fold by the $\mathrm{E}$-test ${ }^{30}$.

Like the present study, false-resistant outcomes (i.e. MEs) have also been reported in previous studies $^{29,30}$. The explanation provided by Marchaim et al. is that $\mathrm{E}$-test detects heteroresistance that is very common in A. baumannii and cannot be identified by broth methods ${ }^{34}$. The phenomenon of increased MICs by Etest is unique only for $A$. baumannii and has not been detected in Enterobacteriaceae ${ }^{34}$. The resistance to tigecycline was predominantly associated with VIMproducing organisms. Nonetheless, a limitation of this study was that the MBL-positive isolates from the nursing home in Zagreb belonged to a single clone. It is difficult to explain the reason for cross-resistance in MBL-positive isolates since MBLs are encoded on mobile genetic elements, whereas tigecycline resistance is due to hyperexpression of efflux pumps. A possible explanation may be that the carbapenemaseproducing organisms have a greater ability to acquire other resistance traits as well.

\section{Conclusions}

Given that BMM is time-consuming and necessitates educated staff, it is not routinely performed in most laboratories. Instead, either the E-test or Vitek 2 is preferred. Clinicians and laboratory personnel alike should be made aware of the discordances between Etest and other microbial sensitivity testing methods, particularly in critically ill patients. Therefore, according to our results, BMM should be recommended for TST of $A$. baumannii. 


\section{References}

1. Robledo IE, Aquino EE, Santé MI, Santana JL, Otero DM, León CF, et al. Detection of KPC in Acinetobacter spp. in Puerto Rico. Antimicrob Agents Chemother. 2010;54:1354-7, https://dx.doi.org/10.1128/AAC.00899-09

2. Cornaglia G, Riccio ML, Mazzariol A, Lauretti L, Fontana R, Rossolini GM. Appearance of IMP-1 metallo-beta-lactamase in Europe. Lancet. 1999;353:899-900.

3. Amudhan MS, Sekar U, Kamalanathan A, Balaraman S. $\mathrm{Bla}(\mathrm{IMP})$ and bla(VIM) mediated carbapenem resistance in Pseudomonas and Acinetobacter species in India. J Infect Dev Ctries. 2012;6:757-62, https://dx.doi.org/10.3855/jidc.2268

4. El-Ageery SM, Al-Hazmi SS. Microbiology and molecular detection of VIM-1 metallo beta lactamase-producing Acinetobacter baumannii. Eur Rev Med Pharmacol Sci. 2014;18: 965-70.

5. Lee K, Yum JH, Yong D, Lee HM, Kim HD, Docquier JD, et al. Novel acquired metallo-beta-lactamase gene, bla(SIM-1), in a class 1 integron from Acinetobacter baumannii clinical isolates from Korea. Antimicrob Agents Chemother. 2005;49:4485-91, https://dx.doi.org/10.1128/AAC.49.11.4485-4491.2005

6. Hrabák J, Stolbová M, Studentová V, Fridrichová M, Chudáčková E, Zemlickova H. NDM-1 producing Acinetobacter baumannii isolated from a patient repatriated to the Czech Republic from Egypt, July 2011. Euro Surveill. 2012;17.

7. Brown S, Amyes S. OXA (beta)-lactamases in Acinetobacter: the story so far. J Antimicrob Chemother. 2006;57:1-3, https:// dx.doi.org/10.1093/jac/dki425

8. Stoeva T, Higgins PG, Bojkova K, Seifert H. Clonal spread of carbapenem-resistant OXA-23-positive Acinetobacter baumannii in a Bulgarian university hospital. Clin Microbiol Infect. 2008;14:723-7, https://dx.doi.org/10.1111/j.1469-0691.2008.02018.x

9. Bou G, Oliver A, Martínez-Beltrán J. OXA-24, a novel class D beta-lactamase with carbapenemase activity in an Acinetobacter baumannii clinical strain. Antimicrob Agents Chemother. 2000;44:1556-61.

10. Pournaras S, Markogiannakis A, Ikonomidis A, Kondyli L, Bethimouti K, Maniatis AN, et al. Outbreak of multiple clones of imipenem-resistant Acinetobacter baumannii isolates expressing OXA-58 carbapenemase in an intensive care unit. J Antimicrob Chemother. 2006;57:557-61, https://dx.doi.org/10.1093/jac/dk1004

11. Higgins PG, Poirel L, Lehmann M, Nordmann P, Seifert H. OXA-143, a novel carbapenem-hydrolyzing class D beta-lactamase in Acinetobacter baumannii. Antimicrob Agents Chemother. 2009;53:5035-8, https://dx.doi.org/10.1128/AAC.00856-09

12. Higgins PG, Pérez-Llarena FJ, Zander E, Fernández A, Bou G, Seifert H. OXA-235, a novel class D $\beta$-lactamase involved in resistance to carbapenems in Acinetobacter baumannii. Antimicrob Agents Chemother. 2013;57:2121-6, https://dx.doi. org/10.1128/AAC.02413-12
13. Poirel L, Nordmann P. Carbapenem resistance in Acinetobacter baumannii: mechanisms and epidemiology. Clin Microbiol Infect. 2006;12:826-36, https://dx.doi.org/10.1111/j.1469-0691.2006.01456.x

14. Goic-Barisic I, Bedenic B, Tonkic M, Katic S, Kalenic S, Punda-Polic V. First report of molecular characterization of carbapenem-resistant Acinetobacter baumannii in different intensive care units in University Hospital Split, Croatia. J Chemother. 2007;19:462-4, https://dx.doi.org/10.1179/joc.2007.19.4.462

15. Goic-Barisic I, Bedenic B, Tonkic M, Novak A, Katic S, Kalenic $\mathrm{S}$, et al. Occurrence of OXA-107 and ISAba1 in carbapenem-resistant isolates of Acinetobacter baumannii from Croatia. J Clin Microbiol. 2009;47:3348-9, https://dx.doi.org/10.1128/JCM.02394-08

16. Franolić-Kukina I, Bedenić B, Budimir A, Herljević Z, Vraneš J, Higgins PG. Clonal spread of carbapenem-resistant OXA-72-positive Acinetobacter baumannii in a Croatian university hospital. Int J Infect Dis. 2011;15:e706-9, https://dx.doi.org/10.1016/j.jijid.2011.05.016

17. Vranić-Ladavac M, Bedenić B, Minandri F, Ištok M, Bošnjak $Z$, Frančula-Zaninović S, et al. Carbapenem resistance and acquired class D beta-lactamases in Acinetobacter baumannii from Croatia 2009-2010. Eur J Clin Microbiol Infect Dis. 2014;33:471-8, https://dx.doi.org/10.1007/s10096-013-1991-9

18. Bedenić B, Beader N, Godič-Torkar K, Vranić-Ladavac M, Luxner J, Veir Z, et al. Nursing home as a reservoir of carbapenem-resistant Acinetobacter baumannii. Microb Drug Resist. 2015;21:270-8, https://dx.doi.org/10.1089/mdr.2014.0157

19. Ladavac R, Bedenić B, Vranić-Ladavac M, Barišić N, Karčić N, Pompe K, et al. Emergence of different Acinetobacter baumannii clones in a Croatian hospital and correlation with antibiotic susceptibility. J Glob Antimicrob Resist. 2017;10:213-8, https://dx.doi.org/10.1016/j.jgar.2017.07.001

20. Petrović T, Uzunović S, Barišić I, Luxner J, Grisold A, Zarfel $\mathrm{G}$, et al. Arrival of carbapenem-hydrolyzing-oxacillinases in Acinetobacter baumannii in Bosnia and Herzegovina. Infect Genet Evol. 2018;58:192-8, https://dx.doi.org/10.1016/j. meegid.2017.12.021

21. Hrenovic J, Durn G, Goic-Barisic I, Kovacic A. Occurrence of an environmental Acinetobacter baumannii strain similar to a clinical isolate in paleosol from Croatia. Appl Environ Microbiol. 2014;80:2860-6, https://dx.doi.org/10.1128/AEM.00312-14

22. Hrenovic J, Durn G, Music MS, Dekic S, Troskot-Corbic T, Skoric D. Extensively and multi drug-resistant Acinetobacter baumannii recovered from technosol at a dump site in Croatia. Sci Total Environ. 2017;607-608:1049-55, https://dx.doi. org/10.1016/j.scitotenv.2017.07.108

23. Hrenovic J, Goic-Barisic I, Kazazic S, Kovacic A, Ganjto M, Tonkic M. Carbapenem-resistant isolates of Acinetobacter baumannii in a municipal wastewater treatment plant, Croatia, 2014. Euro Surveill. 2016:14;21, https://dx.doi.org/10.2807/1560-7917.ES.2016.21.15.30195 
24. Mammina C, Palma DM, Bonura C, Aleo A, Fasciana T, Sodano $\mathrm{C}$, et al. Epidemiology and clonality of carbapenem-resistant Acinetobacter baumannii from an intensive care unit in Palermo, Italy. BMC Res Notes. 2012;5:365, https://dx.doi. org/10.1186/1756-0500-5-365

25. Peleg AY, Seifert H, Paterson DL. Acinetobacter baumannii: emergence of a successful pathogen. Clin Microbiol Rev. 2008;21:538-82, https://dx.doi.org/10.1128/CMR.00058-07

26. Cai Y, Wang R, Liang B, Bai N, Liu Y. Systematic review and meta-analysis of the effectiveness and safety of tigecycline for treatment of infectious disease. Antimicrob Agents Chemother. 2011;55:1162-72, https://dx.doi.org/10.1128/AAC.01402-10

27. Al-Sweih NA, Al-Hubail MA, Rotimi VO. Emergence of tigecycline and colistin resistance in Acinetobacter species isolated from patients in Kuwait hospitals. J Chemother. 2011;23:13-6, https://dx.doi.org/10.1179/joc.2011.23.1.13

28. Clinical and Laboratory Standards Institute. Performance standards for antimicrobial susceptibility testing; Twentyfourth informational supplement. CLSI document M100-S24. Wayne, PA: Clinical and Laboratory Standards Institute; 2014.

29. Grandesso S, Sapino B, Amici G, Mazzucato D. Solinas M, Gion M. Are E-test and Vitek 2 good choices for tigecycline susceptibility testing when comparing broth microdilution for MDR and XDR Acinetobacter baumannii? New Microbiol 2014;37:503-8.
30. Zarkotou O, Pournaras S, Altouvas G, Pitiriga V, Tziraki M, Mamali $\mathrm{V}$, et al. Comparative evaluation of tigecycline susceptibility testing method for expanded-spectrum cephalosporinand carbapenem-resistant gram-negative pathogens. J Clin Microbiol. 2012;50:3747-50, https://dx.doi.org/10.1128/JCM.02037-12

31. Magiorakos AP, Srinivasan A, Carey RB, Carmeli Y, Falagas $\mathrm{ME}$, Giske CG, et al. Multidrug-resistant, extensively drugresistant and pandrug-resistant bacteria: an international expert proposal for interim standard definitions for acquired resistance. Clin Microbiol Infect. 2012;18:268-81, https://dx.doi.org/10.1111/j.1469-0691.2011.03570.x

32. European Committee on Antimicrobial Susceptibility Testing (EUCAST). 2012. Breakpoint tables for interpretation of MICs and zone diameters. Version 2.0, valid from 2012-01-01. http://www.eucast.org/clinical_breakpoints/

33. U. S. Food and Drug Administration. Recognized antibacterial susceptibility test interpretative criteria; 2018, accessed 12 March 2018.

34. Marchaim D, Pogue JM, Tzuman O, Hayakawa K, Lephart $\mathrm{PR}$, Salimnia $\mathrm{H}$, et al. Major variation in MICs of tigecycline in gram-negative bacilli as a function of testing method.J Clin Microbiol. 2014;52:1617-21, https://dx.doi.org/10.1128/JCM.00001-14

Sažetak

\title{
USPOREDBA DVIJU RAZLIČITIH METODA ZA TESTIRANJE OSJETLJIVOSTI NA TIGECIKLIN U ACINETOBACTER BAUMANNII
}

\author{
B. Bedenić, G. Cavric, M. Vranić-Ladavac, N. Barišic, N. Karčić, T. Tot, A. Presečki-Stanko, \\ A. Lukić-Grlić, S. Frančula-Zaninovići K.B. Sreter
}

Testiranje osjetljivosti na tigeciklin (TST) je velik izazov za kliničke mikrobiologe. Prethodna istraživanja su pokazala da E-test i Vitek 2 daju veće vrijednosti minimalne inhibitorne koncentracije tigeciklina u odnosu na dilucijsku metodu, što uzrokuje vrlo veliku grešku (engl. very major error, što znači da je rezistentan izolat proglašen osjetljivim). Cilj istraživanja bio je usporediti dvije metode za testiranje osjetljivosti na tigeciklin (E-test i bujonska dilucijska metoda) u karbapenem osjetljvim i karbapenem rezistentnim izolatima Acinetobacter (A.) baumannii s različitim tipovima karbapenem-hidrolizirajućih oksacilinazama i analizirati promjenu u stopama osjetljivosti na tigeciklin u dva razdoblja istraživanja (2009.-2012. i 2013.2014.). Dilucija u bujonu je bila referentna metoda. Testiranje osjetljivosti na tigeciklin je provedeno E-testom i bujonskom mikrodilucijskom metodom. Prema kriterijima EUCAST-a stopa rezistencije bila je 54,5\% (6/11) za OXA-23 MBL-pozitivne sojeve, 29,4\% (5/17) za OXA-23 MBL-negativne sojeve i 2,7\% (1/37) za karbapenemaza-negativne sojeve uz bujonsku mikrodilucijsku metodu. OXA-24/40 i OXA-58 producirajući sojevi nisu iskazivali rezistenciju. E-testom su svi OXA-23 MBL pozitivni organizmi (11/11), 23,5\% (4/17) OXA-23 MBL negativnih i 4,1\% OXA-24/40 (3/74) pokazivali rezistenciju na tigeciklin. Svi OXA-58 pozitivni i karbapenemaza-negativni sojevi su bili osjetljivi na tigeciklin u E-testu. Rezistencija na tigeciklin se pojavila u razdoblju od 2013. do 2014. godine. Iako tigeciklin ne pokazuje križnu rezistenciju s drugim antibioticima najviše stope rezistencije su zapažene među VIM-pozitivnim izolatima bez obzira na metodu testiranja. Prema rezultatima našega istraživanja komercijalni E-test ne daje pouzdane rezultate TST u A. baumannii. Potrebna je potvrda dilucijskom metodom, osobito kod teških infekcija.

Ključne riječi: Tigeciklin; Disk difuzija, antimikrobni testovi; Mikrobi, testovi osjetliivosti; Acinetobacter baumannii; Lijekovi, rezistencija, bakterijska 